\title{
DistRIBUTION AND ABUNDANCE OF Spotted Owls in Zion National Park
}

\author{
R. J. GUTIÉRREZ $\downarrow$ SARAH RINKEVICH \\ Department of Wildlife $\downarrow$ Humboldt State University \\ Arcata, CA
}

\section{$\downarrow \quad$ INTRODUCTION}

The recent listing of the Northern spotted owl (Strix occidentalis caurina) by the U.S. Fish and Wildlife Service as a threatened species (Federal Register 1990) raises heated debate concerning the long-term survival of the species and perceived economic cost to timber industry (Thomas et al. 1988). Long term studies of the owls's ecology are necessary to provide information needed for ecologically based management plans (Dawson et al. 1987). Much is already known about the natural and life history of the Northern spotted owl (Forsman et al. 1984, Gutiérrez et al. 1984, Gutiérrez 1985, Franklin et al. 1990) as well as the California subspecies (S. o. occidentalis) (Gutiérrez and Pritchard 1990). In contrast, the Mexican spotted owl (S. o. lucida) is the least studied of the three subspecies (Ganey and Balda 1989). It is known that this latter subspecies inhabits rocky canyonlands and coniferous forests in the southwestern United States and Mexico (Kertell 1977, Wagner et al. 1982, Webb 1983, Johnson and Johnson 1985, Ganey 1988, and Skaggs 1988) but there are few published studies on its ecology and habitat needs (Ganey 1988). Also, the effects of human activities, such as recreation, on the Mexican subspecies are unclear, particularly in isolated habitats (Gutiérrez 1985). Therefore, in 1989, we initiated a two year investigation of abundance and distribution of Mexican spotted owls in Zion National Park. This report summarizes our 1990 survey effort and research findings.

\section{$\downarrow$ Methods}

We located owls by imitating owl vocalizations during day and night surveys (Forsman 1983, Franklin et al. 1990) between April 1 and August 13, 1990. We used cruise, point and walk-in surveys (Franklin et al. 1990) with some modifications to account for the rugged canyon country of Zion Park. Cruise surveys were conducted by calling every $30-60$ seconds while hiking canyons or trails. In addition, we called for 10 min at prominent canyon overlooks during these surveys. Point surveys were conducted on ridge and mesa tops using an $45.7 \mathrm{~cm}$ diameter plastic parabolic dish and microphone for 3-5 hour periods between 2000 and 0500 hours (Mountain Standard Time). During these listening periods we called for 10 minutes once every hour and listened forresponses the remainder of the hour. We also conducted daytime walk-in surveys throughout canyons to locate owl roost sites. We allowed at least five days between our surveys at a particular location. Used roost sites were also located which were characterized by feathers, pellets and white wash. Sex of owls was determined by voice; females having a higher pitch than males (Forsman 1983). Our main emphasis in 1990 was locating new owls and resighting owls previously located. We also searched in historical owl sites. In addition, we assessed reproductive status (Forsman 1983).

We captured owls using a noosepole (Forsman 1983). Each individual was marked with an aluminum 
U.S. Fish and Wildlife Service leg-band on one leg and a color-band on the other leg. A $2 \mathrm{~cm}$ long colored, vinyl tab was attached to each color band which provided unique combinations for individual identification (Franklin et al. 1987). We identified owls from our 1989 survey year by resighting their color band. We collected morphologic measurements from each captured owl. We estimated age by plumage characteristics and categorized owls as adult, subadult or juvenile (Forsman 1981). In addition, we collected pellets and recorded habitat characteristics at each owl site.

\section{$\downarrow \quad$ Results}

We spent approximately 2,060 hours over the course of 103 days surveying owls. In addition, we hiked $618 \mathrm{~km}$ on and off trail to gain access and conduct surveys. One hundred and ten surveys were conducted; of these, 43 were conducted using the parabolic dish. We estimated that we had surveyed 90 percent of the available habitat at least once in Zion Park. Eight pellets were collected from two territories, which will be pooled with samples collected in 1989 . Our food habit analysis will be presented in our 1991 Final Report.

We located six pairs and two single birds in eight locations. We located a pair of spotted owls with two juveniles in upper Pine Creek Canyon, and banded both juveniles. The female was never sighted and the male was banded the previous year. A second pair was located in Echo Canyon, with one juvenile. This pair had also been banded the previous year. A third, presumed pair was heard in Oak Creek Canyon in high cliff sites, inaccessible for capture. A fourth pair was found in Kolob Creek Canyon, $1.5 \mathrm{~km}$ north of the park boundary. A fifth, presumed pair was found in Orderville Canyon, and a sixth, presumed pair was heard in a hanging canyon below Lady Mountain. The two latter pairs were located using the parabolic dish, and were also inaccessible for captures. Other responses included a male in La Verkin Creek (Willis Creek vicinity), and a single male in Refrigerator Canyon. All adult owls from the 1989 survey were relocated except for the single male in Camp Creek, and the single male in South Fork of Taylor Creek (Larry Hays 1989, per. comm.).

\section{Discussion}

Spotted owls were uncommon, but widely distributed in Zion National Park, and appeared coincident with a patchy, disjunct habitat. All owls were found in steep-walled canyons or deep gorges. Access was a major problem encountered while surveying Zion, but our greatest problem was surveying hanging canyons where owls lived. Since the rate of erosion of these hanging canyons lags behind that of the main canyon, they drain a smaller watershed and thus, create a refuge for spotted owls that were generally inaccessible to biologists. Three of the eight owl sites located this year were in hanging canyons, and one other site contained hanging canyons within the main canyon (Table 1). Fewer pellets were collected during 1990 than in 1989. In several instances, our method for surveying these hanging drainages (climbing neighboring mesa tops to gain a vantage point) proved successful in finding owls. We believe the parabolic dish greatly improved our chances of hearing an owl when surveying this type of potential habitat.

Although six new adult spotted owls were located during intensive surveys (Table 2), we believe there is a low density of spotted owls in Zion Park relative to other spotted owl populations in North America. Absolute density provides an initial step in estimating owl abundance (Franklin et al. 1990), and can be further subdivided into crude density (i.e., measured with respect to all of the area containing the population) and ecological density (i.e., measured with respect to a particular habitat) (Johnson 1978:11, Tanner 1978:2). Although calculating the latter will require more knowledge of the owl's habitat requirements in the park, we will estimate crude density in our 1991 Final Report.

We suggest that hot weather may have decreased owl responses during 1989 surveys. We also suggest that low numbers of responses on the Colorado Plateau in general could be related to detectibility (i.e., owls were more difficult to hear in the canyon country) or reproductive activity (non-reproductive owls may have lower response rates). This may again explain the enigmatic situation of low owl responses which occurred throughout the Colorado Plateau and areas in Northern Arizona during 1990 surveys. However, we were unable to test these potential influencing factors on calling rate. Again, no owls were detected on Dixie National Forests lands in southern Utah (S. Boyce, 
pers. comm.) but two owls were detected in Texas Canyon (Abajo Mountains) on the Mante LaSalle National Forest (D. Willey, pers. comm.). Willey (pers. comm.) also reported five owls sighted at Capitol Reef National Park, two sightings in Dirty Devil Canyon east of Capitol Reef (BLM), four owls in Canyonlands National Park and five birds near Mesa
Verde. Despite extensive surveys by the U.S. Forest Service no owls were located on the North Kaibab area in northern Arizona (K. Menasco, pers. comm.). Menasco (pers. comm.) also reported only three confirmed spotted owl territories on the South Kaibab Plateau.

Table 1. Summary of locations, status and brief canyon description of spotted owls found between 1 April - 13 August, Zion National Park, Utah.

\begin{tabular}{|c|c|c|c|}
\hline$\overline{\text { LOCATION }}$ & $\begin{array}{l}\text { NUMBER } \\
(\mathrm{N}=14)\end{array}$ & STATUS & $\begin{array}{l}\text { CANYON } \\
\text { DESCRIPTION }\end{array}$ \\
\hline Echo Canyon & 3 & $\begin{array}{l}1 \text { pair } \\
\text { w/ } 1 \text { juvenile }{ }^{1}\end{array}$ & Narrow gorge \\
\hline $\begin{array}{l}\text { Kolob Creek Canyon } \\
\text { canyon }\end{array}$ & 2 & 1 pair & High-walled \\
\hline Lady Mt. Canyon & 2 & 1 pair ${ }^{1}$ & Hanging canyon \\
\hline La Verkin Creek & 1 & 1 male, status & Steep-walls/cliff \\
\hline Oak Creek Canyon & 2 & 1 pair & $\begin{array}{l}\text { Hanging canyon } \\
\text { w/ cliff sites }\end{array}$ \\
\hline Orderville Canyon & 2 & 1 pair $^{1}$ & High-walledcanyon \\
\hline Pine Creek Canyon & 4 & 1 pair $^{1,2}$ & $\begin{array}{l}\text { Narrow canyon } \\
\text { w/ hanging } \\
\text { canyons present }\end{array}$ \\
\hline $\begin{array}{l}\text { Refrigerator } \\
\text { unknown }\end{array}$ & 1 & 1 male, status & $\begin{array}{l}\text { Hanging canyon } \\
\text { Canyon }\end{array}$ \\
\hline
\end{tabular}

${ }^{1}$ New birds for 1990 that were undetected during the 1989 survey effort.

${ }^{2}$ Male (only) was detected in 1989. 
Table 2. Location and number of spotted owl surveys conducted between 1 April - 13 August 1990, Zion National Park, Utah.

\begin{tabular}{|c|c|c|}
\hline LOCATION & NUMBER OF SURVEYS & RESULTS \\
\hline Beartrap Canyon & 1 & No response \\
\hline Camp Creek & 1 & No response \\
\hline Canyon Overlook Trail ${ }^{2}$ & 2 & No response \\
\hline Court of Patriarchs & 2 & No response \\
\hline Deep Creek ${ }^{4}$ & 2 & No response \\
\hline Echo Canyon ${ }^{2}$ & 3 & $\begin{array}{l}1 \text { pair (banded 1989) } \\
\text { w/ juveniles }\end{array}$ \\
\hline Gifford Canyon ${ }^{2}$ & 5 & No response \\
\hline Goose Creek ${ }^{4}$ & 4 & No response \\
\hline Heaps Canyon² (top) & 4 & No response \\
\hline Hepworth $^{2}$ (top) & 2 & No response \\
\hline Hidden Canyon ${ }^{2}$ & 4 & 1 male (Echo Terr.) \\
\hline Kolob Arch Canyon & 2 & No response \\
\hline Kolob Creek Canyon & 4 & 1 male, 1 female(pair) \\
\hline La Verkin Creek & 1 & $1 \mathrm{male}$ \\
\hline Lady Mt. Canyon ${ }^{4}$ (top) & 1 & $\begin{array}{l}1 \text { male, } 1 \text { female } \\
\text { (unconfirmed pair) }\end{array}$ \\
\hline Lava Point ${ }^{2}$ & 1 & No response \\
\hline Left Fork (top) & 1 & No response \\
\hline MIA Road (call route) & 2 & No response \\
\hline Middle Fork Taylor Creek & 2 & No response \\
\hline North Fork Taylor Creek & 2 & No response \\
\hline Oak Creek $^{2}$ & 7 & $\begin{array}{l}1 \text { male, } 1 \text { female } \\
\text { (unconfirmed pair) }\end{array}$ \\
\hline Orderville Canyon ${ }^{2,4}$ & 5 & $\begin{array}{l}1 \text { male, } 1 \text { female } \\
\text { (unconfirmed pair) }\end{array}$ \\
\hline Pine Creek ${ }^{2}$ & 4 & $\begin{array}{l}1 \text { male (banded 1989), } \\
1 \text { female } w / 2 \text { juv. } \\
\text { (banded } 2 \text { juveniles) }\end{array}$ \\
\hline Phantom Canyon (top) & 3 & No response \\
\hline $\begin{array}{l}\text { Potato Hollow }{ }^{2} \text {, and } \\
\text { top of Imlay Canyon }\end{array}$ & 3 & No response \\
\hline Refrigerator Canyon² & 7 & $\begin{array}{l}1 \text { male (social status } \\
\text { unknown) }\end{array}$ \\
\hline Right Fork North Ck (top) & 2 & No response \\
\hline South Fork Taylor Creek & 3 & No response \\
\hline Telephone Canyon & 1 & No response \\
\hline West Rim Trail (route) & 3 & No response \\
\hline Wildcat Canyon (top) & 1 & No response \\
\hline Willis Creek & 1 & No response \\
\hline Canyon 4 (3293E, 41205N) & 1 & No response \\
\hline Canyon 5 (3299E, 41209N) & 1 & No response \\
\hline Canyon 6 (3301E, 41211N) & 1 & No response \\
\hline Canyon 7 (3305E, 41214N) & 1 & No response \\
\hline
\end{tabular}


Table 2 cont. LOCATION

NUMBER OF SURVEYS RESULTS

Canyon 8 (3312E, 41213N)

Canyon 9 (3314E, 41215N)

No response

Canyon 10 (3314E, 41224N)

No response

Canyon 11 (3327E, 41217N)

No response

Canyon 13 (3327E, 41213N)

No response

Canyon $14(3316 \mathrm{E}, 41210 \mathrm{~N})$

No response

Canyon 15 (3308E, 41209N)

No response

Canyon 16 (3299E, 41213N)

No response

Canyon $17(3288 \mathrm{E}, 41212 \mathrm{~N})$

No response

${ }^{1}$ L. Hays, Resource Officer, Zion National Park.

${ }^{2}$ The approximate historic sighting location.

${ }^{3}$ Universal transverse mercator coordinates represent location at the mouth of the given canyon; 7.5 Minute Series (topographic) Springdale East Quadrangle, Utah.

${ }^{4}$ New areas, not surveyed during the 1989 survey.

C. Dargon (pers. comm.) reported 98-100 spotted owl territories on the Coconino National Forest. During 1989, Joe Ganey (pers. comm.) reported only 70 responses on the Coconino National Forest.

In general, the low number of spotted owl responses maybe the result of a low density of spotted owls throughout southern Utah, northern Arizona and parts of the Colorado Plateau. We are unable to speculate if there is a relationship between habitat quality and the number of owls detected at this time. Further population characteristics are needed to fully understand Mexican spotted owl since density alone is not an indicator of habitat quality (Van Horne 1983).

\section{$\downarrow$ ACKNOWLEDGEMENTS}

We thank Michael Alexander for field assistance during April and May; his dedication and enthusiasm under difficult field conditions was greatly appreciated. S. Finn assisted in surveying and captures during June - August. D. Willey, S. Boyce, K. Menasco and C. Dargan contributed information on the Colorado Plateau. We also thank L. Hays for his various forms of assistance as well as J. Gentry and the Zion Natural History Association for their financial assistance. A special thanks goes to Susan Small for her support and generous contribution to this project. John Hiratsuka supplied film and slide development for both survey seasons. We also thank Hi-Tec and Royal Robbins for their contributions. This study was funded by the University of Wyoming-National Park Service Research Center (order no. PX-1200-9-C820).

\section{$\downarrow$ Personal Communications}

Boyce, S., Dixie National Forest, P.O. Box 580, Cedar City, Utah 84721-0580.

Dargan, C., Coconino National Forest, 2323 E. Green Lane, Flagstaff, Arizona 86004.

Ganey, J., Dept. Biology, Northern Arizona Univ., Flagstaff, Arizona 86001.

Hays, L., Resource Management, Zion National Park, Springdale, Utah 84767.

Menasco, K., Kaibab National Forest, 800 South 6th Street, Williams, Arizona 86046.

Willey, D., High Desert Research Collective, P.O. Box 136, Torrey, Utah 84775. 


\section{Literature Cited}

Dawson, W. R., J. D. Ligon, J. R. Murphy, J. P. Myers, D. Simberloff, and J. Verner. 1987. Report of the scientific advisory panel on the spotted owl. Condor 89:205-229.

Forsman, E. D. 1981. Molt of the spotted owl. Auk. 98:735-742.

Forsman, E. 1983. Methods and materials for studying spotted owls. Pacific Northwest Forest and Range Exper. Stat., Gen. Tech. Rpt. PNW-162. 8 pp.

Forsman, E., E. C. Meslow, and H. Wight. 1984. Distribution and biology of the spotted owl in Oregon. Wildl. Monog. 86. 64 pp.

Franklin, A., J. P. Ward, and R. J. Gutiérrez. 1987. Population ecology of the northern spotted owl (Strix occidentalis caurina) in northwestern California: preliminary results, 1986 . Calif. Dept. Fish and Game Fed. Aid Wildl. Res. Proj. W-65-R-4, Unpubl. Progress Rep. 42 pp.

Franklin, A., J. P. Ward, R. J. Gutiérrez, and G. Gould, Jr. 1990. Density of northern spotted owls in northwest California. J. Wildl. Manage. 54:1-10.

Ganey, J. L. and R. P. Balda. 1989. Distribution and habitat use of Mexican spotted owls in Arizona. The Condor 91:355-361.

Ganey, J. L. 1988. Distribution and habitat ecology of Mexican spotted owls in Arizona. M. S. Thesis. N. Ariz. Univ., Flagstaff, AZ. 229 pp.

Gutiérrez, R. J. and J. Pritchard. 1990. Distribution, density and age structure of spotted owls on two southern California habitat islands. Condor. 92:491-495.

Gutiérrez, R. J. 1985. An overview of recent research on the spotted owl. pp 368-373. In: Gutiérrez, R. J., and A. B. Carey. Tech. Eds. Ecology and Management of Spotted Owls in the Pacific Northwest. Pacific Northwest Forest and Range Exper. Stat. Gen. Tech. Rpt. PNW-185:39-49.

Gutiérrez, R. J., D. M. Solis, and C. Sisco. 1984. Habitat ecology of the spotted owl in northwestern
California: Implications for management. pp 368-373. In: Proc. Conv. Amer. Soc. For. Portland, Oregon.

Johnson, D. R. 1978. The study of raptor populations. Univ. of Idaho Press, Moscow. 57 pp.

Johnson, J. A., and T. H. Johnson. 1985. The status of the spotted owl in northern New Mexico. Contract No. 516.6-73-03. New Mexico Dep. Game and Fish. Santa Fe, NM.

Kertell, K. 1977. The spotted owl in Zion National Park, Utah. West. Birds 8:147-150.

Skaggs, R. W. 1988. Status of the spotted owl in southern New Mexico: 1900-1987. Contract No. 519-75-02. New Mexico Dep. Game and Fish. Santa Fe, NM.

Tanner, J. T. 1978. Guide to the study of animal populations. Univ. Tennessee Press, Knoxville. $186 \mathrm{pp}$.

Thomas, J. W., L. F. Ruggiero, R. W. Mannan, J. W. Schoen, and R. A. Lancia. 1988. Management and conservation of old-growth forests in the United States. Wildl. Soc. Bull. 16:252-262.

U. S. Fish and Wildlife Service. 1990. Endangered and threatened wildlife and plants; determination of threatened status of the Northern spotted owl; Final Report. Fed. Reg. 55, (123):26,114-26,194.

Van Horne, B. 1983. Density as a misleading indicator of habitat quality. J. Wildl. Manage. 47:893-901.

Wagner, P. W., C. D. Marti, and T. C. Boner. 1982. Food habits of the spotted owl in Utah. Raptor Res. 16:27-28.

Webb, B. 1983. Distribution and nesting requirements of montane forest owls in Colorado. IV. Spotted owl (Strix occidentalis). Colo. Field Ornithol. 17:2-8. 